\title{
Effects of shade on growth, biomass allocation and leaf morphology in European yew (Taxus baccata L.)
}

Philip M. Perrin 1, 2 and Fraser J. G. Mitchell1

(1)Department of Botany, Trinity College Dublin, University of Dublin, Dublin 2, Ireland

(2)Present address: BEC Consultants Ltd., Ground Floor Offices, Loft 31, South Cumberland Street, Dublin 2, Ireland

European Journal of Forest Research

March 2013, Volume 132, Issue 2, pp 211-218

\begin{abstract}
The impact of shade on the growth of European yew (Taxus baccata L.) saplings was investigated over a three-year period using artificial shading to simulate four different light regimes $(3,7,27$ and $100 \%$ relative photosynthetic photon flux density, RPPFD). There was no mortality attributable to shading even under the $3 \%$ RPPFD treatment. Increasing shade was positively associated with specific leaf area, leaf length, leaf width and total chlorophyll content, but negatively associated with plant height, stem diameter, total dry weight and root to leaf and shoot ratio. Discoloration of the foliage occurred in plants grown in $100 \%$ RPPFD conditions (resulting in reduced growth rates) and those transferred to $100 \%$ RPPFD conditions after being shade-acclimated for 2 years. Evidence suggests that T. baccata has the ability to regenerate beneath a lighter canopy but beneath denser canopies gap dynamics will play an important role in facilitating successful regeneration and this needs to be reflected in management of natural populations of this declining species.
\end{abstract}

Keywords

Artificial shading Biomass allocation Leaf morphology Natural regeneration Taxus baccata

Introduction

European yew (Taxus baccata L.) is widely regarded as a species in decline across continental Europe (e.g. Hofman 1970; Bugała 1978; Leuthold 1980; Majer 1981; Svenning and Magård 1999; García et al. 2000; Dhar et al. 2006) and is even at risk of becoming regionally extinct (Schirone et al. 2010). The species is afforded legal protection in some European countries (e.g. Poland) and yewdominated woods in Britain and Ireland are listed as priority habitats under Annex I of the EU Habitats Directive (European Commision 2007). Poor rates of regeneration have been reported from many natural populations and this has been related to several factors including seed predation (Hulme 1996), winter frosts (Iszkuło 2010), autotoxicity (Semagina 1983) and herbivore browsing (Mysterud and Østbye 2004; Perrin et al. 2006; Farris and Filigheddu 2008). 
Light conditions and canopy density are, however, known to be key considerations affecting yew regeneration (Iszkuło and Boratyński 2004, 2006). Yew regenerates most readily in thorny scrub where plants receive relatively high light levels, but are mechanically protected from browsing animals (Watt 1926; Tittensor 1980; Hulme 1996; García et al. 2000; Farris and Filigheddu 2008). Perrin et al. (2006) found that in Ireland, in the absence of browsing animals, yew regenerated beneath the lighter, deciduous canopy of sessile oak (Quercus petraea (Matt.) Liebl.), but not beneath the denser, evergreen canopy of yew. Svenning and Magård (1999) reported that sexual activity, strobilus production and recruitment to the sapling stage were all reduced beneath dense canopy, and the felling of beech (Fagus sylvatica L.) and opening up of the canopy were considered by Hulme (1996) to be responsible for strong yew sapling recruitment in a northern England woodland. Gap dynamics and overstory mortality are therefore particularly important considerations for yew regeneration in forests with dense canopies.

Despite favouring these higher light conditions for regeneration, yew is regarded as a shade-tolerant species (Bugała 1978; Brzeziecki and Kienast 1994; Thomas and Polwart 2003). Shade tolerance is the minimum light level required for survival, but Valladares and Niinemets (2008) have argued that rather than this being an absolute value it is a relative concept affected by other biotic or abiotic factors such as drought, waterlogging and herbivory, with tolerance to this interaction also influenced by length of the growing season. Many species with shade tolerance exhibit a functional trade-off with lower tolerances to drought and waterlogging, but T. baccata is unusual, particularly amongst gymnosperms, in being both shade-tolerant and drought-tolerant (Niinemets and Valladares 2006).

Despite interactions with other stress factors, species-relative shade tolerance rankings remain fairly constant (Valladares and Niinemets 2008). In forest communities in Ireland and Britain where T. baccata occurs, yew is ranked as one of the most shade-tolerant of tree species present, whereas in examples of stands in central and Eastern Europe, there are several species with similar or stronger shade tolerance (Table 1).

Table 1

Ellenberg indicator values for light requirement for the main tree species in four European forest communities in which Taxus baccata occurs 


\begin{tabular}{|c|c|c|c|}
\hline \multicolumn{2}{|c|}{$\begin{array}{l}\text { Reenadinna Wood, SW Ireland } \\
\text { (Perrin et al. 2006)* }\end{array}$} & \multicolumn{2}{|c|}{$\begin{array}{l}\text { Taxus baccata woodland of the British National } \\
\text { Vegetation Classification (Rodwell 1991)* }\end{array}$} \\
\hline Corylus avellana & 4 & Fagus sylvatica & 3 \\
\hline Taxus baccata & 4 & Acer pseudoplatanus & 4 \\
\hline Euonymus europaeus & 5 & Taxus baccata & 4 \\
\hline Fraxinus excelsior & 5 & Fraxinus excelsior & 5 \\
\hline Ilex aquifolium & 5 & Ilex aquifolium & 5 \\
\hline Crataegus monogyna & 6 & Crataegus monogyna & 6 \\
\hline Sorbus aucuparia & 6 & Sambucus nigra & 6 \\
\hline Betula pubescens & 7 & Sorbus aria & 6 \\
\hline Quercus robur & 7 & Quercus robur & 7 \\
\hline \multicolumn{2}{|c|}{$\begin{array}{l}\text { Stiwollgraben, Austria (Dhar et al. } \\
2006)^{\star \star \star}\end{array}$} & \multicolumn{2}{|c|}{$\begin{array}{l}\text { Knyazhdvir Nature Reserve, W Ukraine (Iszkuło et al. } \\
2005)^{\star \star}\end{array}$} \\
\hline Abies alba & 3 & Abies alba & 3 \\
\hline Fagus sylvatica & 3 & Acer campestre & 3 \\
\hline Acer pseudoplatanus & 4 & Fagus sylvatica & 3 \\
\hline Fraxinus excelsior & 4 & Acer pseudoplatanus & 4 \\
\hline Taxus baccata & 4 & Prunus avium & 4 \\
\hline Ulmus glabra & 4 & Taxus baccata & 4 \\
\hline Picea abies & 5 & Acer platanoides & 5 \\
\hline Sorbus aria & 6 & Picea abies & 5 \\
\hline Pinus sylvestris & 7 & Cornus sanguineus & 7 \\
\hline \multirow[t]{2}{*}{ Lanix decidua } & 8 & Corylus avellana & 6 \\
\hline & & Sambucus nigra & 7 \\
\hline
\end{tabular}

This scale varies for woody plants from 3 to 9 where 3 indicates plants found in shade and 9 indicates plants found in full light

* Signifies values are from Hill et al. (2004) 
** Signifies values are from Ellenberg et al. (1992)

Phenotypic plasticity tends to be low overall in shade-tolerant plants, for example, they show limited elongation in low light conditions, but they can have considerable plasticity in some features which optimise light capture (Valladares and Niinemets 2008). These include increased chlorophyll content and producing a greater leaf surface area per unit dry mass under shade conditions (Niinemets 2010). Hallik et al. (2009) showed that, within key plant functional types, mean leaf dry mass per area of woody temperate species decreased with increasing shade tolerance. Under low light conditions, both shade-tolerant and shade-intolerant species have been shown to allocate proportionately less biomass to roots (e.g. Reich et al. 1998).

The aim of the experiment reported in this paper was to add to our knowledge of natural regeneration in yew by investigating the impact of shade on the growth, biomass allocation and leaf morphology adaptations of T. baccata saplings.

\section{Methods}

The experiment was conducted on an open plot at Trinity College Botanic Gardens, Dublin, Ireland (latitude $53^{\circ} 20^{\prime} \mathrm{N}$, longitude $6^{\circ} 1^{15^{\prime}}$ W). Young, bare-rooted T. baccata saplings grown from seed and approximately $35 \mathrm{~cm}$ in height were sourced from a commercial nursery. These were planted in $23 \mathrm{~cm}$ diameter plastic pots in a general purpose peat-based compost and randomly allocated to one of five shade treatments ( $n=24$ per treatment). Levels of shading were achieved by growing plants beneath wooden frames $(3.05 \mathrm{~m} \times 2.05$ $\mathrm{m} \times 1.15 \mathrm{~m}$ ) covered on all side by layers of green plastic shade netting (Gardman). The photosynthetic photon flux density (PPFD) available in each treatment was measured on a uniformly overcast day using a quantum sensor (model LI-189, LI-COR Biosciences). This was used to quantify the PPFD available in each shaded treatment relative to the PPFD available for the unshaded control treatment, that is, relative photosynthetic photon flux density (RPPFD) (Table 2). The experiment was run over 3 years. In four treatments (AD), the same shade conditions were maintained in each treatment throughout the experiment but in the fifth treatment (E), plants were grown under heavy shade for 2 years and then transferred to $100 \%$ RPPFD shortly after bud burst in May of the third growing season. This was achieved by removing the shade frame and was intended to simulate canopy removal. An uncovered gap at the bottom of the frames permitted air circulation. Plants were watered by hand as required throughout the experiment and during the growing season plants were fed regularly with a standard liquid NPK plant feed. Global radiation and temperature data for the duration of the experiment are presented in Table 3 (Met Éireann, unpublished data for Dublin Airport $13 \mathrm{~km} \mathrm{~N}$ of the experimental site).

\section{Table 2}

Relative photosynthetic photon flux density (RPPFD) available to plants in each shade treatment 


\begin{tabular}{|c|c|c|}
\hline Treatment & Shading & RPPFD (\%) \\
\hline A & None (control) & 100 \\
\hline B & Low & 27 \\
\hline C & Medium & 7 \\
\hline D & Heavy & 3 \\
\hline \multirow[t]{2}{*}{$\mathrm{E}$} & Heavy (for first and second growing seasons) & 3 \\
\hline & None (for third growing season) & 100 \\
\hline
\end{tabular}

Table 3

Mean global radiation and temperature data from Dublin Airport for 2000-2002

\begin{tabular}{|c|c|c|c|c|c|c|c|c|c|}
\hline Parameter & Jan & Feb & Mar & Apr & May & Jun & Jul & Aug & $\mathrm{S}_{\mathrm{I}}$ \\
\hline $\begin{array}{l}\text { Daily global } \\
\text { radiation }(0 \\
\mathrm{cm}^{-2} \text { ) }\end{array}$ & 241 & 513 & 842 & 1,259 & 1,807 & 1,696 & 1,560 & 1,367 & $9 \varsigma$ \\
\hline $\begin{array}{l}\text { Daily } \\
\text { maximum } \\
\text { temperature } \\
\left({ }^{\circ} \mathrm{C}\right)\end{array}$ & 8.1 & 9.2 & 10.1 & 11.4 & 15.4 & 17.2 & 18.9 & 19.3 & 17 \\
\hline $\begin{array}{l}\text { Daily } \\
\text { minimum } \\
\text { temperature } \\
\left({ }^{\circ} \mathrm{C}\right)\end{array}$ & 2.1 & 2.0 & 2.9 & 3.1 & 6.4 & 8.8 & 10.5 & 10.7 & 8. \\
\hline
\end{tabular}

Data from Met Éireann

The experiment was initiated in February 2000. At that time the height of each plant (from level of root collar to highest living bud) and the stem diameter $2 \mathrm{~cm}$ above the root collar were measured. After the first growing season, in December 2000, the height of all plants was re-measured and eight plants from treatments A, B, C and D were randomly selected for harvest. From each harvested plant, twenty leaves were removed, five from the midpoint of each of the top four lateral shoots of current-year growth. These sampled leaves were scanned using a standard PC scanner and the resulting digitised leaf images were analysed using the Scion Image software (Scion Corporation) to obtain the mean area, length and width of leaves from each plant. The dry weight of sampled leaves, remaining new leaf and shoot biomass, old leaf and shoot biomass and root biomass for each harvested plant was measured after drying material in an oven for $72 \mathrm{~h}$ at $75^{\circ} \mathrm{C}$. Combined measurements were made for leaf and shoot biomass. Eight plants were also removed from treatment $\mathrm{E}$ to keep the number of plants per treatment equal and the plants remaining in each treatment were repositioned to maintain plant density.

After the second growing season, in January 2002, the height and basal diameter of all plants were re-measured. Eight plants were again randomly selected and removed from each treatment and biomass and leaf measurements were 
recorded as detailed above for treatments A, B, C and D. In addition, chlorophyll content was measured from bulked leaf samples from three plants randomly selected from each of treatments A, B, C and D (approximately fifteen leaves per treatment). Following determination of fresh weight, chlorophyll was extracted with $80 \%$ acetone from ground samples and extracts were centrifuged at $500 \times$ g. Replicated measurements $(n=5)$ of the light absorbance of these samples at a wavelength of $652 \mathrm{~nm}$ were made using a spectrophotometer. Total chlorophyll content was then calculated following Hall and Rao (1994). After the third growing season, in late 2002, the height and basal diameter of all remaining plants were again re-measured.

Data were investigated using ANOVA with Tukey's HSD post hoc test.

\section{Results}

No mortality attributable to the effects of shade occurred during the experiment. In winter 2000, after the first growing season, foliage of plants in the control group (treatment A) developed a bronzy discoloration on the upper surface, possibly as a result of frost or exposure. This resulted in poor growth of these plants in the second and third growing seasons. Exposure of plants in treatment E to full light at the start of the third growing season resulted in a rapid bleaching effect of the foliage.

At the start of the experiment, there were no significant differences in mean height between the treatments (Fig. $1 \mathrm{a}, \mathrm{P}=0.183$ ). After the first growing season, plants in treatment $\mathrm{B}$ (light shade) were significantly taller than plants under medium and heavy shade treatments (Fig. $1 \mathrm{~b}, \mathrm{P}=0.002$ ). No significant differences in height occurred at the end of the second growing season (Fig. 1c, P $=0.147$ ). At the end of the third growing season, the poorly growing plants in treatment A were significantly shorter than those in treatments B (light shade) and $C$ (medium shade) (Fig. $1 \mathrm{~d}, \mathrm{P}=0.008$ ). Although there was no significant difference in height between plants in treatments $B, C$ and $D$, there was a trend of decreasing height with increasing shade. Exposure of plants in treatment $\mathrm{E}$ to full light conditions after two growing seasons in heavy shade did not result in a significant difference in height compared with treatment $D$, where plants had remained in heavy shade for all three seasons. 


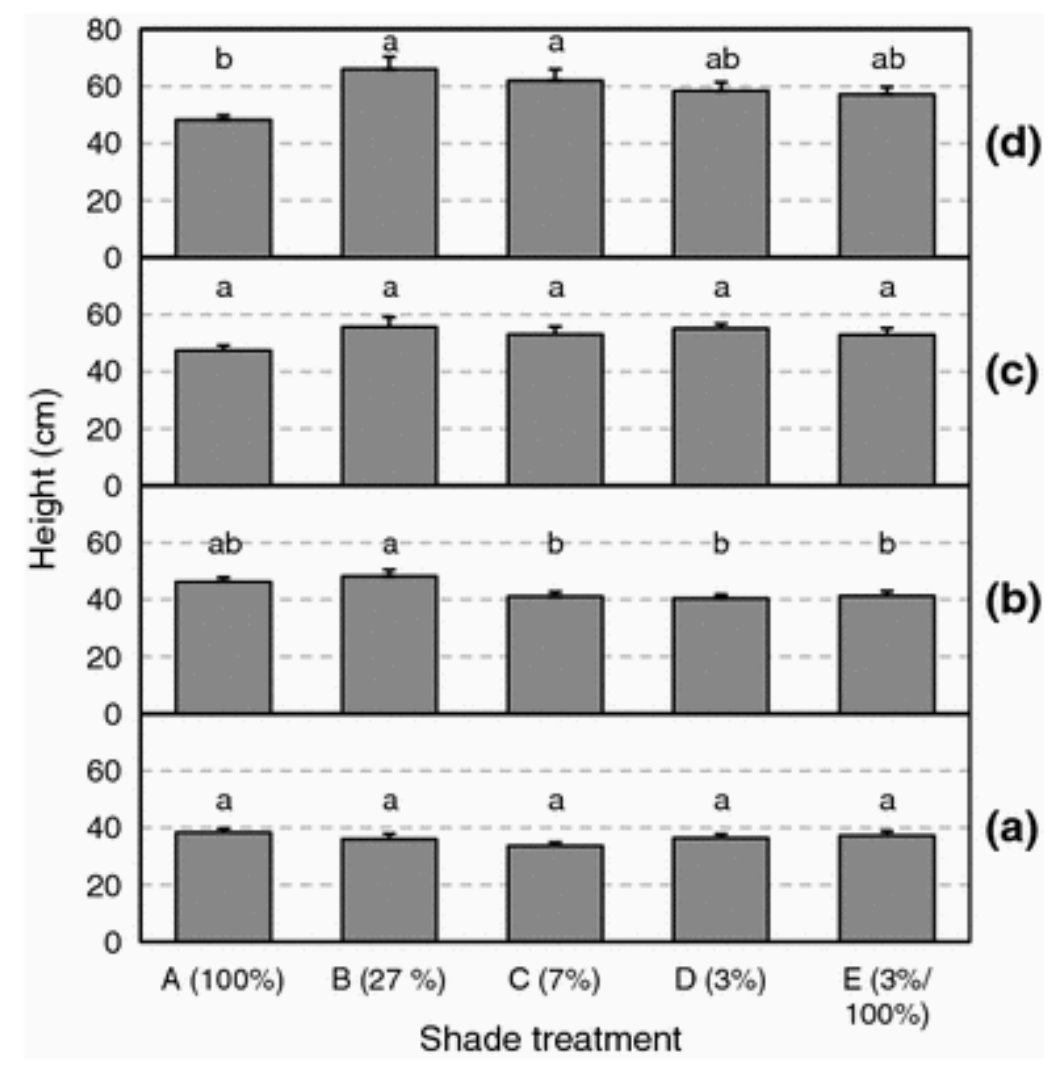

Fig. 1

Mean height $(\mathrm{cm})$ of yew saplings grown under different shade treatments: a at start of experiment; b after first growing season; c after second growing season; $\mathrm{d}$ after third growing season. Percentages indicate RPPFD available to each treatment, with treatment E being 3 \% RPPFD in graphs (a), (b) and (c) and $100 \%$ in graph (d). Vertical bars indicate se. Within each graph, lower-case letters indicate homogeneous subsets according to Tukey's HSD post hoc test

Basal diameter did not differ significantly at the start of the experiment (Fig. 2a, $\mathrm{P}=0.388$ ) but after two growing seasons shading had clearly had an effect, with this measurement being significantly smaller as shade increased (Fig. $2 \mathrm{~b}, \mathrm{P}<$ 0.001). A similar pattern occurred after the third growing season (Fig. 2c, P < 0.001). Exposure of plants in treatment $\mathrm{E}$ to full light conditions after two growing seasons in heavy shade resulted in a trend for markedly greater basal diameter after the third growing season compared with treatment D. 


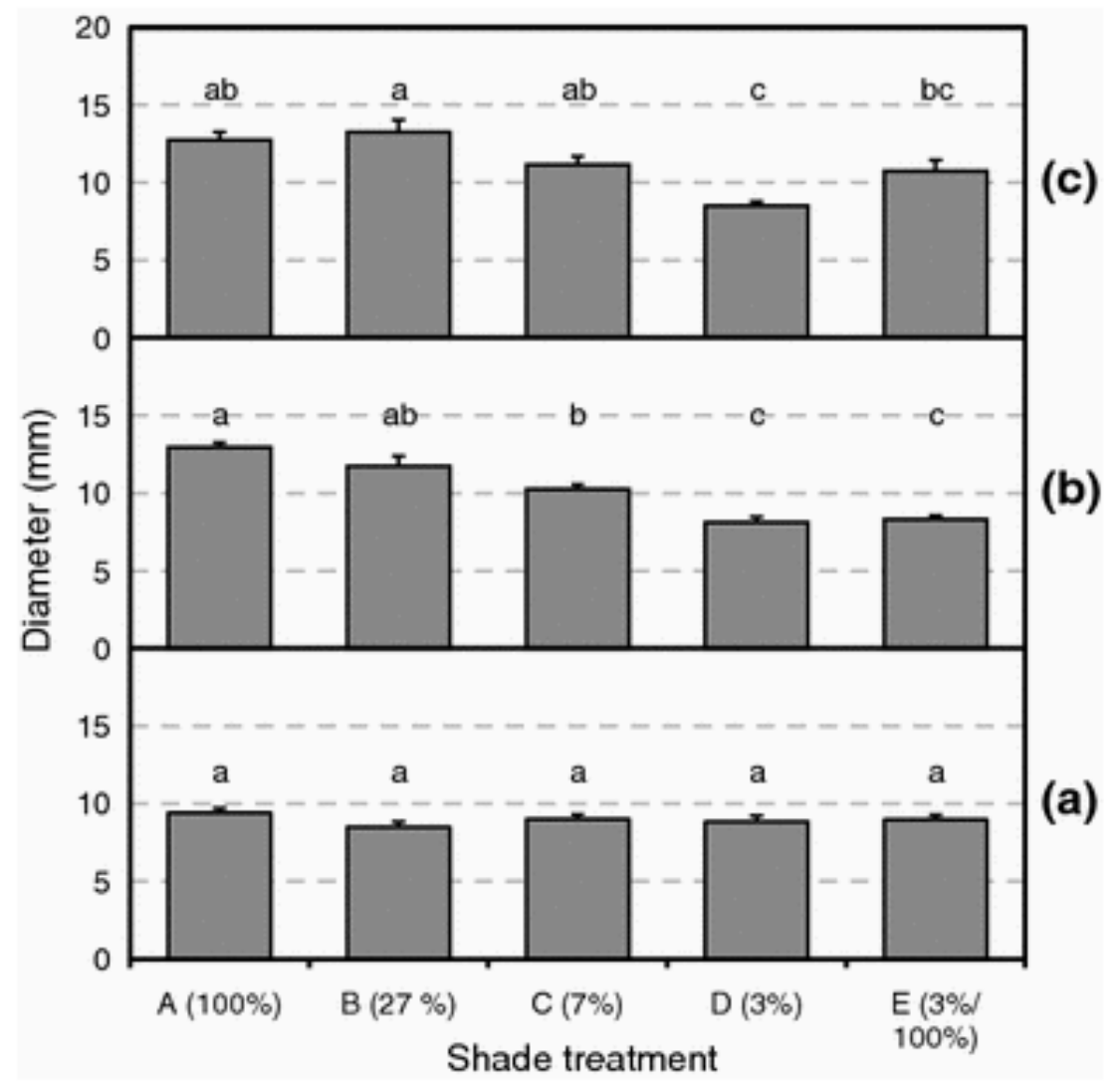

Fig. 2

Mean basal diameter ( $\mathrm{mm}$ ) of yew saplings grown under different shade treatments: a at start of experiment; $b$ after second growing season; $c$ after third growing season. Percentages indicate RPPFD available to each treatment, with treatment $\mathrm{E}$ being 3 \% RPPFD in graphs (a) and (b) and $100 \%$ in graph (c).Vertical bars indicate se. Within each graph, lower-case letters indicate homogeneous subsets according to Tukey's HSD post hoc test

Mean total dry weight of plants harvested after the first growing season differed significantly between treatments (Table 4) with plants under the heavy shading (treatment D) being less than half the weight of the unshaded controls (treatment A). Root to leaf and shoot dry weight ratio also differed significantly between treatments after the first growing season with leaves and shoots comprising a smaller proportion of total dry weight in the unshaded plants (treatment A) and plants under low shade (treatment B) than in the other treatments. After the second growing season, these patterns had become more pronounced with plants in treatment $\mathrm{D}$ being less than a third of the dry weight of plants in treatment $A$, and with root to leaf and shoot ratio declining significantly with increasing shade.

Table 4

Dry weight proportions and root to leaf and shoot ratio of yew saplings grown under different shade treatments for one and two growing seasons 


\begin{tabular}{|c|c|c|c|c|c|}
\hline Treatment & $\begin{array}{l}\text { New leaves } \\
\text { and shoots } \\
(\%)\end{array}$ & $\begin{array}{l}\text { Old leaves } \\
\text { and shoots } \\
(\%)\end{array}$ & Roots (\%) & $\begin{array}{l}\text { Root: leaf } \\
\text { and shoot }\end{array}$ & $\begin{array}{l}\text { Total } \\
\text { (g) }\end{array}$ \\
\hline \multicolumn{6}{|c|}{ After first growing season } \\
\hline A & $16.5 \pm 1.5 a$ & $30.9 \pm 3.0 \mathrm{a}$ & $52.6 \pm 4.5 a$ & $1.13 \pm 0.07 a$ & 103.9 \\
\hline B & $17.7 \pm 1.5 a$ & $31.9 \pm 2.5 a$ & $50.4 \pm 4.6 a$ & $1.02 \pm 0.07 a$ & 86.3 \\
\hline C & $18.0 \pm 1.4 a$ & $41.4 \pm 3.2 \mathrm{ab}$ & $40.6 \pm 4.2 a$ & $0.68 \pm 0.04 b$ & 52.2 \\
\hline D & $10.5 \pm 1.8 b$ & $47.9 \pm 5.9 b$ & $41.6 \pm 6.7 a$ & $0.70 \pm 0.06 b$ & 36.3 \\
\hline$P$ & $* *$ & $*$ & n.s. & $*$ & $* *$ \\
\hline \multicolumn{6}{|c|}{ After second growing season } \\
\hline A & $2.5 \pm 0.6 a$ & $42.2 \pm 3.4 a$ & $55.3 \pm 6.5 a$ & $1.22 \pm 0.09 a$ & 148.3 \\
\hline B & $9.4 \pm 3.7 a b$ & $44.1 \pm 8.9 a$ & $46.5 \pm 8.0 a b$ & $0.97 \pm 0.07 a$ & 106.2 \\
\hline C & $11.8 \pm 2.1 b$ & $50.1 \pm 5.4 a$ & $38.1 \pm 4.8 \mathrm{ab}$ & $0.63 \pm 0.07 b$ & 83.0 \\
\hline D & $10.1 \pm 1.4 a b$ & $61.6 \pm 5.9 a$ & $28.3 \pm 3.2 a$ & $0.41 \pm 0.05 b$ & 46.6 \\
\hline$P$ & * & n.s. & * & $\cdots$ & $* * *$ \\
\hline
\end{tabular}

Values are presented with se. Within columns for each growing season, lowercase letters indicate homogeneous subsets according to Tukey's HSD post hoc test

ANOVA: ${ }^{*}<0.05,{ }^{* *}<0.01,{ }^{* * *}<0.001$, n.s. indicates not significant

Increased levels of shade resulted in a higher specific leaf area (SLA) (Table 5). This was due primarily to larger leaf area; leaves under heavier shade were both longer and wider than leaves under low shade or no shade. Chlorophyll content of foliage grown in the second year differed significantly between treatments (Table 6, $\mathrm{P}<0.001$ ) with higher levels of chlorophyll in the plants under medium and heavy shade.

Table 5

Mean leaf length $(\mathrm{mm})$, width $(\mathrm{mm})$, area $(\mathrm{cm} 2)$, dry weight $(\mathrm{mg})$ and specific leaf area (SLA; cm2 g-1) of current-year foliage from yew saplings grown under artificial shade for one and two growing seasons 


\begin{tabular}{|c|c|c|c|c|c|}
\hline Treatment & Length & Width & Area & $\begin{array}{l}\text { Dry } \\
\text { weight }\end{array}$ & SLA \\
\hline \multicolumn{6}{|c|}{ After first growing season } \\
\hline A & $19.48 \pm 0.47 a$ & $2.59 \pm 0.04 a$ & $0.43 \pm 0.02 a$ & $4.2 \pm 0.2 a$ & $103.0 \pm 3.4 \mathrm{a}$ \\
\hline B & $21.03 \pm 1.27 a b$ & $2.75 \pm 0.09 a b$ & $0.49 \pm 0.05 a$ & $4.3 \pm 0.5 a$ & $116.3 \pm 6.2 a$ \\
\hline C & $21.06 \pm 1.26 \mathrm{ab}$ & $2.92 \pm 0.10 a b$ & $0.51 \pm 0.05 a$ & $3.1 \pm 0.4 a$ & $172.8 \pm 8.5 b$ \\
\hline D & $24.08 \pm 1.14 b$ & $3.09 \pm 0.17 b$ & $0.59 \pm 0.04 a$ & $2.9 \pm 0.3 a$ & $209.2 \pm 11.7 c$ \\
\hline$P$ & * & * & n.s. & * & $\cdots$ \\
\hline \multicolumn{6}{|c|}{ After second growing season } \\
\hline A & $9.82 \pm 0.97 a$ & $2.23 \pm 0.12 a$ & $0.17 \pm 0.03 a$ & $1.7 \pm 0.4 a$ & $115.2 \pm 6.0 \mathrm{a}$ \\
\hline B & $16.95 \pm 2.48 b$ & $2.69 \pm 0.14 b$ & $0.41 \pm 0.08 b$ & $3.5 \pm 0.8 a b$ & $122.5 \pm 5.1 \mathrm{a}$ \\
\hline C & $19.52 \pm 0.58 b c$ & $3.35 \pm 0.08 c$ & $0.55 \pm 0.02 b c$ & $3.7 \pm 0.2 b$ & $149.6 \pm 4.6 b$ \\
\hline D & $24.02 \pm 0.81 c$ & $3.45 \pm 0.12 c$ & $0.71 \pm 0.03 c$ & $3.5 \pm 0.3 a b$ & $208.2 \pm 10.2 c$ \\
\hline$P$ & $* * *$ & $\star * *$ & *** & * & $* *$ \\
\hline
\end{tabular}

Values are presented with se. Within columns for each growing season, lowercase letters signify homogeneous subsets according to Tukey's HSD post hoc test ANOVA: ${ }^{*}<0.05, * * *<0.001$, n.s. indicates not significant

Table 6

Chlorophyll content (mg g-1 fresh weight) of current-year leaves of yew saplings grown under different shade treatments for two growing season

\begin{tabular}{|c|c|c|}
\hline Treatment & RPPFD (\%) & Chlorophyll content \\
\hline A & 100 & $0.33 \pm 0.42 \mathrm{a}$ \\
\hline B & 27 & $0.49 \pm 0.11 \mathrm{a}$ \\
\hline C & 7 & $1.26 \pm 0.07 \mathrm{~b}$ \\
\hline D & 3 & $1.97 \pm 0.06 \mathrm{~b}$ \\
\hline
\end{tabular}

Values are presented with se. Lower-case letters indicate homogeneous subsets according to Tukey's HSD post hoc test 


\section{Discussion}

The experiment demonstrated that $\mathrm{T}$. baccata growing under shade conditions exhibits growth and leaf morphology adaptations. Saplings survived under $3 \%$ RPPFD conditions for 3 years. However, smaller plants are apparently less able to survive in dense shade conditions; Iszkuło and Boratyński (2004) found that whilst seedlings of yew (less than $25 \mathrm{~cm}$ tall) were most frequent beneath conifer trees including mature yews, regeneration over $1 \mathrm{~m}$ in height was most frequent beneath a broadleaf canopy. Hence, survival rates of seedlings are higher under a lighter, deciduous broadleaf canopy.

After 3 years, there was a general trend of greater height and stem diameter with increasing light levels between treatments B, C and D. A correlation between height and light availability has been found in an in situ experiment with $\mathrm{T}$. baccata seedlings beneath a deciduous canopy (Iszkuło et al. 2007). Conversely, in shade-intolerant species significant increases in height occur under lower light conditions, for example, pedunculate oak (Quercus robur L.) (Welander and Ottoson 1998). Root collar diameter increment has been found to decline with increased shade in other conifer species (Kennedy et al. 2007). Whilst transfer of plants from $3 \%$ RPPFD to unshaded conditions did not significantly increase the height of plants (possibly due to the damage to foliage), there was a positive response in stem diameter.

Specific leaf area (SLA) is indicative of the light levels in which foliage has grown. Increases in SLA by plants grown under lower light levels have been reported for many conifer species covering a range of shade tolerance (Mitchell 1998; Reich et al. 1998; Awada et al. 2003; Qu et al. 2005). T. baccata evidently has a considerable plasticity in the morphology of new leaves with plants grown under heavy shade (3\% RPPFD) having almost twice the SLA of unshaded plants. Increasing SLA in T. baccata seedlings with decreasing light levels was observed by Iszkuło (2010) who also reported similar relative differences between shade treatments.

Increasing shade resulted in reduced total dry weight as found in other conifer studies (e.g. Khan et al. 2000; Qu et al. 2005). With increasing shade, biomass allocation was shifted from roots to leaves and shoots, a strategy characteristic of shade-acclimated plants (Givnish 1988). Whilst leaf and shoot biomass were not examined separately in the present study, Iszkuło (2010) reported that in T. baccata seedlings grown under artificial shade, leaf biomass allocation and shoot biomass allocation both increased with increasing shade. In contrast, Reich et al. (1998) found that for a range of tree species, increased shade caused a decrease in root biomass allocation and an increase in shoot biomass allocation, but no significant change in leaf biomass allocation, although that investigation was confined to 5 and $25 \%$ light treatments. Whilst the magnitude of these changes in biomass allocation differed by species in Reich's study, there was no pattern in relation to shade tolerance, hence biomass allocation is not diagnostic of shade strategy. 
Plants grown in unshaded conditions and shade-adapted plants transferred to unshaded conditions suffered from damage to foliage. Damage to the plants grown in treatment A (100\% RPPFD) may have been due to exposure to full sunlight, winter frosts or a combination of these factors. Yew populations in England achieve a maximum tolerance to cold in mid winter (January), but cold hardiness then declines rapidly, therefore plants are susceptible to spring frosts (Melzack and Watts 1980). Frost is a major cause of mortality of yew seedlings in Poland (Iszkuło 2010), but the climate in Ireland is much milder than that in Eastern Europe. As occurs in natural populations, the plants grown in the full sunlight treatment will have been more exposed than those grown under shade. Damage to the plants in treatment $\mathrm{E}$ following transfer appears to be due to the unsuitability of shade-adapted foliage to full sunlight conditions, possibly due to the development of a thin waxy cuticle in deep shade; this layer protects plant tissues from excessive insolation. When plants are transferred to a different light regime, T. baccata needles grown in previous years have been shown to have no acclimative ability in their size or mesophyll structure (Wyka et al. 2008). It has also been reported that, whilst yew seedlings growing in the shade of their parent trees produce dark green leaves, those occurring in the open grow little and have leaves that turn orangey-brown in colour (Smith 1980). Mitchell (1998) found that sun-grown T. baccata foliage had a higher SLA and foliar N content than Pacific yew (T. brevifolia Nutt.) and suggested that T. baccata was therefore more tolerant of full irradiance than T. brevifolia. Bugała (1978) states that yew plants grown in the shade and transplanted into the open do not survive. In contrast, there is good evidence that, within woodland, opening up of the canopy has a positive effect on yew regeneration (Mitchell 1988, 1990; Hulme 1996; Svenning and Magård 1999). This suggests that, whilst shadeadapted yew is able to respond with increased growth to the medium increases in light levels associated with the development of canopy gaps, such plants are less able to adapt to full sunlight conditions. This regeneration strategy is similar to the 'Oskar syndrome' described by Silvertown (1982) where a pool of juveniles can survive for many years under heavy shade waiting for a canopy gap to appear and can then exploit the gap ahead of new regeneration from other species.

\section{Conclusions}

Plants grown under low light conditions display reduced growth rates, and changes to leaf morphology, chlorophyll content and biomass allocation, but no mortality attributable to shade. This tolerance appears to enable T. baccata, in the absence of other limiting factors, to regenerate successfully beneath lighter canopies. However, denser canopies such as those cast by conifers including yew itself may inhibit regeneration. The management implications of this concur with the recommendations proposed by Czatoryski (1978) and Svenning and Magård (1999) and investigated by Dhar et al. (2006), where selective felling to create broken or thin canopy conditions may be a valid management tool for promoting regeneration in natural populations of yew where it occurs in the understory of 
mixed forests. Where the aim is to re-establish or reinforce a population within woodland, underplanting beneath lighter canopies is also feasible.

Acknowledgments

This project was part of a wider investigation into the ecology of Taxus baccata funded by the National Parks and Wildlife Service of the Irish government. We would like to thank Dr. Steve Waldren and the staff of the Trinity College Botanic Garden for their assistance throughout the experiment and Prof. Michael B. Jones for comments on a draft of the manuscript. Two anonymous reviewers made many helpful suggestions. 
Awada T, Radoglou K, Fotelli MN, Constantinidou HIA (2003) Ecophysiology of seedlings of three Mediterranean pine species in contrasting light regimes. Tree Physiol 23:33-41

Brzeziecki B, Kienast F (1994) Classifying the life-history strategies of trees on the basis of the Grimean model. For Ecol Manage 69:167-187

Bugała W (1978) Systematics and variability. In: Bialobok S (ed) The yewTaxus baccata L. Foreign Scientific Publications Department of the National Center for Scientific, Technical and Economic Information, Warsaw, pp 15-31

Czatoryski A (1978) Protection and conservation of yew. In: Bialobok S (ed) The yew-Taxus baccata L. Foreign Scientific Publications Department of the National Center for Scientific, Technical and Economic Information, Warsaw, pp 116-138

Dhar A, Ruprecht H, Klumpp R, Vacik H (2006) Stand structure and natural regeneration of Taxus baccata at "Stiwollgraben" in Austria. Dendrobiology $56: 19-26$

Ellenberg H, Weber HE, Düll R, Wirth V, Werner W, Paulißen D (1992)

Zeigerwerte von Pflanzen in Mitteleuropa, 2nd edn. Scr Geobot 18:1-258

European Commission (2007) Interpretation manual of European Union habitats-EUR27. DG Environment, European Commission

Farris E, Filigheddu R (2008) Effects of browsing in relation to vegetation cover on common yew (Taxus baccata L.) recruitment in Mediterranean environments. Plant Ecol 199:309-318.

García D, Zamora R, Hódar JA, Gómez JM, Castro J (2000) Yew (Taxus baccata L.) regeneration is facilitated by fruity-fleshed shrubs in Mediterranean environments. Biol Conserv 95:31-38.

Givnish TJ (1988) Adaptation to sun and shade: a whole-plant perspective. Aust J Plant Physiol 15:63-92.

Hall D, Rao K (1994) Photosynthesis, 5th edn. Cambridge University Press, Cambridge

Hallik L, Niinemets Ü, Wright IJ (2009) Are species shade and drought tolerance reflected in leaf-level structural and functional differentiation in Northern Hemisphere temperate woody flora? New Phytol 184:257-274.

Hill MO, Preston CD, Roy DB (2004) PLANTATT—attributes of British and Irish plants: status, size, life history, geography and habitats. Centre for Ecology and Hydrology, Huntingdon

Hofman J (1970) The changes in historical and contemporaneous distribution of yew in Bohemia from an ecological standpoint. Preslia 42:170-183

Hulme PE (1996) Natural regeneration of yew (Taxus baccata L.): microsite, seed or herbivore limitation? J Ecol 84:853-861. 
Iszkuło G (2010) Success and failure of endangered tree species: low temperatures and low light availability affect survival and growth of European yew (Taxus baccata L.) seedlings. Pol J Ecol 58:259-271

Iszkuło G, Boratyński A (2004) Interaction between canopy tree species and European yew Taxus baccata (Taxaceae). Pol J Ecol 52:523-531

Iszkuło G, Boratyński A (2006) Analysis of the relationship between photosynthetic photon flux density and natural Taxus baccata seedlings occurrence. Acta Oecol 29:78-84.

Iszkuło G, Boratyński A, Didukh Y, Romaschenko K, Pryazhko N (2005) Changes of population structure of Taxus baccata L. during 25 years in protected area (Carpathians, Western Ukraine). Pol J Ecol 53:13-23

Iszkuło G, Lewandowski A, Jasinska AK, Dering M (2007) Light limitation of growth in 10-year-old seedlings of Taxus baccata L. (European yew). Pol J Ecol $55: 827-831$

Kennedy S, Black K, O’Reilly C, Ní Dhubháin Á (2007) The impact of shade on growth, morphology and biomass allocation in Picea sitchensis, Larix $\times$ eurolepsis and Thuja plicata. New Forest 33:139-153.

Khan SR, Rose R, Haase DL, Sabin TE (2000) Effects of shade on morphology, chlorophyll concentration, and chlorophyll fluorescence of four Pacific Northwest conifer species. New Forest 19:171-186.

Leuthold C (1980) Die ökologische und pflanzensoziologische Stellung der Eibe (Taxus baccata) in der Schweiz [The ecological and phytosociological position of the yew (Taxus baccata) in Switzerland]. Veröff Geobot Inst Eidg Tech Hochsh Stift Rübel Zür 67:1-224 (In German)

Majer A (1981) The yew tree-rich beech forest of Bakony-Szentagal, western Hungary. Acta Bot Acad Sci Hung 27:53-104

Melzack RN, Watts D (1980) Cold hardiness in the yew (Taxus baccata L.) in Britain. J Biogeogr 9:231-241.

Mitchell FJG (1988) The vegetational history of the Killarney oakwoods, SW Ireland: evidence from fine spatial resolution pollen analysis. J Ecol 76:415-436.

Mitchell FJG (1990) The impact of grazing and human disturbance on the dynamics of woodland in S.W. Ireland. J Veg Sci 1:245-254.

Mitchell AK (1998) Acclimation of Pacific yew (Taxus brevifolia) foliage to sun and shade. Tree Physiol 18:749-757.

Mysterud A, Østbye E (2004) Roe deer (Capreolus capreolus) browsing pressure affects yew (Taxus baccata) recruitment within nature reserves in Norway. Biol Conserv 120:545-548. 
Niinemets Ü (2010) A review of light interception in plant stands from leaf to canopy in different plant functional types and in species with varying shade tolerance. Ecol Res 25:693-714.

Niinemets Ü, Valladares F (2006) Tolerance to shade, drought, and waterlogging of temperate Northern Hemisphere trees and shrubs. Ecol Monogr 76:521-547.

Perrin PM, Kelly DL, Mitchell FJG (2006) Long-term deer exclusion in yew-wood and oakwood habitats in southwest Ireland: natural regeneration and stand dynamics. For Ecol Manage 236:356-367.

Qu L, Ji D, Shi F, Sasa K, Koike T (2005) Growth and photosynthetic performance of seedlings of two larch species grown in shaded conditions. Eurasian J For Res 8:43-51

Reich PB, Tjoelker MG, Walters MB, Vanderklein DW, Buschena C (1998) Close association of RGR, leaf and root morphology, seed mass and shade tolerance in seedlings of nine boreal trees species grown in high and low light. Funct Ecol 12:327-328.

Rodwell JS (ed) (1991) British plant communities. Vol 1, Woodlands and scrub. Cambridge University Press, Cambridge

Schirone B, Ferreira RC, Vessella F, Schirone A, Piredda R, Simeone MC (2010) Taxus baccata in the Azores: a relict form at risk of imminent extinction. Biodivers Conserv 19:1547-1565.

Semagina RN (1983) State of natural renewal of common yew (Taxus baccata) in Black Sea forests of the Caucasian reservation. Byull Mosk Ova Ispyt Prir Otd Biol 88:146-149

Silvertown JW (1982) Introduction to plant population ecology. Longman, London

Smith CJ (1980) Ecology of the English chalk. Academic Press, London

Svenning J-C, Magård E (1999) Population ecology and conservation status of the last natural population of English yew Taxus baccata in Denmark. Biol Conserv 88:173-182.

Thomas PA, Polwart A (2003) Taxus baccata L. Biological flora of the British Isles. J Ecol 91:489-524.

Tittensor RM (1980) Ecological history of yew Taxus baccata L. in southern England. Biol Conserv 17:243-265.

Valladares F, Niinemets Ü (2008) Shade tolerance, a key plant feature of complex nature and consequences. Annu Rev Ecol Evol Syst 39:237-257.

Watt AS (1926) Yew communities of the South Downs. J Ecol 14:282-316. 
Welander NT, Ottoson B (1998) The influence of shading on growth and morphology in seedlings of Quercus robur L. and Fagus sylvatica L. For Ecol Manage 107:117-126.

Wyka T, Robakowski P, Żytkowiak R (2008) Leaf age as a factor in anatomical and physiological acclimative responses of Taxus baccata L. needles to contrasting irradiance environments. Phytosynth Res 95:87-99. 